South-West Africa in Early Times

Being the Story of South-West Africa up to the Date of Maharero's Death in 1890. By Dr. Heinrich Vedder. Translated and edited by Dr. Cyril G. Hall. Pp. xvi $+525+12$ plates. (London: Oxford University Press, 1938.) 15s. net.

A LTHOUGH this book, originally published in A German, is in name a history, the author's conception of the scope of his subject has necessitated a very full treatment of the ethnology and racial movements of the native peoples, Bushmen, Herero, Nama, Bergdama and Ovambo. Full use has been made of much valuable, but unpublished and inaccessible material, especially the remarkable collection in twenty-seven volumes of records of the "Sources of the History of South-West Africa", which has been taken into safe custody by the Administration.

The author's sifting of the material provided by his authorities is cautious and thorough. His discussion of the famous rock-engravings and cave paintings deserves attention. In the light of his experience of the native peoples, and his tests of their reactions, he is of the opinion that, while the engravings are the work of an ancient and vanished race, the paintings are relatively modern, and in all probability the work of the Bushman.

The English edition omits certain quotations of original documents, and curtails accounts of the development of certain vanished mission stations, while adding illustrations and maps. As a summary and critical account of unpublished material, the book is of considerable value to the student of the history of the South African native peoples and their relations one to another, as well as to the white man.

\section{A Catalogue of Vertebrates of Japan}

By Yaichiro Okada. Pp. vi +412. (Tokyo : Maruzen Co., Ltd., 1938.) 12s.

THIS valuable work presents every appearance of careful compilation to show the composition and range of the components of Japan's vertebrate fauna. It indicates, by the way, the intensity of systematic work in Japan since von Siebold's "Fauna Japonica" was completed in 1860, for the fauna at present contains 3,823 vertebrates, whereas in 1860 only 646 were known. The classes were represented now and then as follows: mammals 375 (57); birds 873 (201); reptiles 158 (18); amphibians 76 (11); cephalocorda 1 (0); cyclostomes $7(0)$; fishes 2,251 (359). A rough glance through the contents shows that of non-migratory land forms, mammals, reptiles and amphibians, a very high proportion of the subspecies are peculiar to Japan and the neighbouring Korea and Formosa, whereas aquatic species and birds are more widely distributed. But it is surprising to find that among the mammals and birds only three mammals, the common house mouse, the mongoose and a deer, and three birds, are regarded as having been introduced from other countries. All the cosmopolitan rats are listed as original natives of Japan. The thoroughness of Prof. Okada's work is suggested by the extent of the index, which itself occupies 93 pages.

J. R.

\section{J. Chr. Fabricius Systema Glossatorum}

Im Anhang: K. Illiger, Die neueste GattungsEintheilung der Schmetterlinge aus den Linnéischen Gattungen Papilio und Sphinx; J. Chr. Fabricius, Rechenschaft an das Publicum über seine Classification der Glossaten. Herausgegeben von Felix Bryk. (Sammlung naturwissenschaftlicher Facsimile-Drucke, Band 1.) Pp. xii $+112+13+4$. (Neubrandenburg: Gustav Feller, 1938.)

THE "Systema Glossatorum" was the last work of the great Danish taxonomist, J. Chr. Fabricius, and is of fundamental importance to those who are concerned with the nomenclature of butterflies. It is, furthermore, a publication of the greatest rarity, and apparently only two examples exist of the original in the Latin language (1807). The present work reproduces in facsimile the original text of Fabricius, which is thus now rendered accessible to all and sundry who are concerned with taxonomy. As supplements there are also included facsimile reproductions of Illiger's "Gattungs-Eintheilung der Schmetterlinge" and Fabricius's brief Rechenschaft of his classification of Glossata.

A. D. I.

\section{Faunistischer Führer durch die Coleopteren-}

Literatur

Die wichtigste Käfer-Literatur nach geographischen Gebieten geordnet. Von S. Schenkling. Band 1 : Europa. Lieferung 1. Pp. 64. 6 gold marks. Lieferung 2. Pp. 65-128. 6 gold marks. (Neubrandenburg: Gustav Feller, 1938.)

7 HIS work aims at being a guide to the more important faunistic literature on the Coleoptera, which is arranged according to the geographical regions. Volume 1, it is announced, will consist of about ten Lieferungen and these are concerned with the general Palæarctic region and with Europe. Volume 2 is to treat of the literature referring to palæarctic Asia and Africa together with the IndoMalayan region; Volume 3 with Ethiopia, Australia and Oceania and Volume 4 with America.

A specialized work of this kind should prove a valuable aid to the taxonomist and especially to students in the great museums. A survey of the two parts already published makes it evident that this "Führer" will simplify the task of searching the literature in any particular group of these insects inhabiting a specified country or region.

\section{Einführung in die theoretische Physik}

Von Prof. Dr. Clemens Schaefer. Band 3, Teil 2 : Quantentheorie. Pp. vii +510. (Berlin und Leipzig: Walter de Gruyter und Co., 1937.) 26 gold marks.

THIS substantial volume forms one part of a comprehensive "Introduction to Theoretical Physics" written by Dr. Schaefer of Breslau, and is concerned with quantum theory, treated mainly from a mathematical point of view. About one half of the book relates to the theory of Bohr, for the author considers that this is historically correct and also represents the best approach to wave mechanics. The final chapter deals with Dirac's theory of the electron and positron. 